\title{
Hubungan Pola Makan Dengan Kadar Gula Darah Pada Penderita Diabetes Mellitus
}

\author{
Susanti ${ }^{1}$, Difran Nobel Bistara ${ }^{2}$ \\ Akademi Keperawatan Adi Husada Surabaya ${ }^{1}$ \\ Fakultas Keperawatan dan Kebidanan Universitas Nahdlatul Ulama Surabaya ${ }^{2}$ \\ susanti@akper-adihusada.ac.id, nobel@unusa.ac.id
}

\begin{abstract}
ABSTRAK
Latar Belakang: Pola makan merupakan asupan makanan yang memberikan berbagai macam jumlah, jadwal dan jenis makanan yang didapatkan seseorang. Pengaturan pola makan yang tidak tepat seperti yang dianjurkan 3J (Jadwal, Jumlah dan Jenis) dapat mengakibatkan peningkatan kadar gula darah.

Tujuan: Penelitian ini bertujuan untuk mengidentifikasi hubungan pola makan dengan kadar gula darah pada penderita Diabetes mellitus.

Metode: Desain penelitian ini adalah korelasional. Variabel bebas yaitu pola makan dan variabel terikatnya yaitu kadar gula darah. Pengambilan sampel dilakukan di Puskesmas Tembok Dukuh Surabaya dengan memakai teknik purposive sampling. Pengambilan sampel dilakukan pada bulan Oktober sampai November 2017 dengan besar sampel 40 responden. Data yang diperoleh dengan menggunakan lembar kuesioner dan observasi. Skala pengumpulan data ordinal dengan uji statistik yang dipergunakan pada penelitian ini menggunakan korelasi Spearman Rank.

Hasil: Hasil uji statistik Spearman Rho $\mathrm{p}=0,000(=0,05)$ menunjukkan bahwa $\mathrm{H}_{0}$ ditolak sehingga dapat disimpulkan ada hubungan antara pola makan dengan kadar gula darah pada penderita Diabetes Mellitus di Puskesmas Tembok Dukuh Surabaya. Hasil penelitian ini didapatkan ada hubungan yang kuat antara pola makan dengan kadar gula darah apabila pola makan yang tidak baik seperti yang dianjurkan prinsip 3J maka akan terjadi ketidakstabilan kadar gula darah.

Kesimpulan: Pentingnya peran pengaturan pola makan pada penderita diabetes dalam pengendalian kadar gula darah sehingga kadar gula darah tetap terkontrol.
\end{abstract}

Kata kunci : pola makan; kadar gula; penyakit diabetes mellitus

\begin{abstract}
Background: Diet is an intake of foods that provide a wide range of the number, schedule, and type of food found someone. The setting is improper diet as recommended 3J (schedule, number, and type) can lead to increased blood sugar levels.

Objective: This study aimed to identify the relationship between diet and blood sugar levels in diabetic people.

Methods: The design used in this study was correlational. Independent variables are diet and the dependent variable is blood sugar levels. Sampling was conducted in Puskesmas Tembok Dukuh. By using purposive sampling, conducted in October to November 2017 with a sample size of 40 respondents. Data were obtained using a questionnaire and observation sheet. Ordinal scale data collection by statistical tests used in this study using Spearman Rank correlation.

Results: The results of Spearman Rho $\mathrm{p}=0.000(=0.05)$ indicating that the $\mathrm{H}_{0}$ is rejected, it can be concluded that there is a relationship between diet and blood sugar levels in patients with Diabetes Mellitus in Puskesmas Tembok Dukuh Surabaya. The results of this study, there is a very strong relationship between diet and blood sugar levels when a diet is not good as recommended principles $3 \mathrm{~J}$, there will be instability in blood sugar levels.

Conclusion: The importance of the role of diet regulation in diabetics is maintaining blood sugar levels so that the blood sugar levels is normal.
\end{abstract}

Keywords: diet; blood sugar levels; diabetes mellitus 


\section{PENDAHULUAN}

Diabetes Mellitus (DM) merupakan salah satu jenis penyakit degeneratif tidak menular yang menjadi masalah serius bagi kesehatan masyarakat di Indonesia maupun di dunia (Krisnatuti \& Yehrina, 2008). Pola makan yang tidak teratur yang terjadi pada masyarakat saat ini dapat menyebabkan terjadinya peningkatan jumlah penyakit degeneratif, salah satunya penyakit DM (Suiraoka, 2012). Penderita DM harus memperhatikan pola makan yang meliputi jadwal, jumlah, dan jenis makanan yang dikonsumsi. Kadar gula darah meningkat dratis setelah mengkonsumsi makanan tertentu karena kecenderungan makanan yang dikonsumsi memiliki kandungan gula darah yang tidak terkontrol (Tandra, 2009).

Saat ini, penderita DM diperkirakan sudah mencapai angka 9,1 juta orang penduduk. Data tersebut menjadikan Indonesia menduduki peringkat ke-5 di dunia dengan penderita DM tertinggi pada tahun 2013 (IDF, 2014). Penyakit DM merupakan salah satu penyebab utama penyakit tidak menular atau 2,1\% dari seluruh kematian yang terjadi. Kasus DM di dunia diperkirakan sebanyak 90\% merupakan DM Tipe II (Perkeni, 2010). Menurut Riskesdas (2013), Provinsi Jawa Timur dengan prevelensi penderita DM sebesar 2,1\% dengan menempati urutan ke-9. Menurut penelitian Susilo (2012), sebanyak 38 responden (63,3\%) penderita DM di Rumah Sakit Baptis Kediri melakukan diet tepat jumlah, sebanyak 35 responden $(58,3 \%)$ melakukan diet tepat jenis, dan sebanyak 44 responden $(73,3 \%)$ tidak melakukan diet tepat jadwal (Susilo, 2012).

Penyakit DM banyak dikenal orang sebagai penyakit yang erat kaitannya dengan asupan makanan. Asupan makanan seperti karbohidrat/ gula, protein, lemak, dan energi yang berlebihan dapat menjadi faktor resiko awal kejadian DM. Semakin berlebihan asupan makanan maka semakin besar pula kemungkinan akan menyebabkan DM (Linder, 2008). Karbohidrat akan dicerna dan diserap dalam bentuk monosakarida, terutama gula. Penyerapan gula menyebabkan peningkatan kadar gula darah dan mendorong peningkatan sekresi hormon insulin untuk mengontrol kadar gula darah (Linder, 2008).

$$
\text { Penyakit Diabetes Melitus }
$$
merupakan penyakit degeneratif yang dapat dikendalikan dengan empat pilar penatalaksaan. Diet menjadi salah satu hal penting dalam empat pilar penatalaksanaan DM dikarenakan pasien tidak memperhatikan asupan makanan yang seimbang. Meningkatnya gula darah pada pasien DM berperan sebagai penyebab dari ketidak seimbangan jumlah insulin, oleh karena itu diet menjadi salah satu pencegahan agar gula darah tidak meningkat, dengan diet yang tepat dapat membantu mengontrol gula darah (Soegondo, (2015).

Pengendalian tingkat gula darah normal memerlukan penatalaksanaan diet DM yang baik dan benar. Motivasi dan dukungan dari konselor gizi juga diperlukan. Hal ini dapat dilaksanakan dengan cara edukasi gizi melalui perencanaan pola makan yang baik. Dalam hal ini diwujudkan Puskesmas Tembok Dukuh dengan mengadakan kegiatan penyuluhan secara berkala dengan harapan penderita diabetes mellitus termotivasi tentang pengontrolan diet 3J (Jumlah, Jadwal dan Jenis) yang dianjurkan sehingga kadar gula darah dapat terkontrol.

\section{METODE}

Desain penelitian yang dipergunakan adalah korelasional. Variabel yang digunakan meliputi variabel bebas yaitu pola makan dan variabel terikat yaitu kadar gula darah. Pengambilan sampel dilakukan di Puskesmas Tembok Dukuh Surabaya dengan menggunakan teknik purposive sampling, yaitu teknik pengambilan sampel dengan kriteria tertentu (Notoatmodjo, 2010; Nursalam, 2013). Pengambilan sampel dilakukan di bulan Oktober sampai November 2017. Besar sampel sebanyak 40 responden dengan kriteria inklusi berupa pasien yang terdaftar di Puskesmas Tembok Dukuh Surabaya, pasien penderita diabetes mellitus, dan pasien bersedia untuk menjadi responden penelitian. Data yang 
diperoleh dengan menggunakan lembar kuesioner dan observasi. Skala pengumpulan data ordinal dengan uji statistik menggunakan korelasi Spearman Rank (Spearman Rho $\mathrm{p}=0,000(=0,05)$ ).

\section{HASIL}

Data Umum

1. Karakteristik Responden Berdasarkan Umur

Tabel 1 Karakteristik Responden Berdasarkan Umur

\begin{tabular}{|c|c|c|c|}
\hline No & Umur & $\mathrm{n}$ & $\%$ \\
\hline 1 & 35-45 Tahun & 9 & 23 \\
\hline 2 & 46-55 Tahun & 15 & 38 \\
\hline 3 & 56-65 Tahun & 13 & 33 \\
\hline \multirow[t]{2}{*}{4} & $>65$ Tahun & 3 & 8 \\
\hline & Jumlah & 40 & 100 \\
\hline
\end{tabular}

sebagian besar responden di Puskesmas Tembok Dukuh Surabaya yaitu berumur 46-55 tahun berjumlah 15 (38\%).

2. Karakteristik Responden Berdasarkan Jenis Kelamin

Tabel 2 Karakteristik Responden Berdasarkan Jenis Kelamin

\begin{tabular}{cccc}
\hline No & Umur & n & \% \\
\hline 1 & Laki-Laki & 16 & 40 \\
2 & Perempuan & 24 & 60 \\
\hline & Jumlah & 40 & 100 \\
\hline
\end{tabular}

Berdasarkan Tabel 2 menunjukkan bahwa sebagian besar responden berjenis kelamin perempuan berjumlah 24 responden (60\%) di Puskesmas Tembok Dukuh Surabaya.

3. Karakteristik Responden Berdasarkan Pendidikan

Tabel 3 Karakteristik Responden Berdasarkan Pendidikan

\begin{tabular}{|c|c|c|c|}
\hline No. & Pendidikan & $\mathbf{n}$ & $\%$ \\
\hline 1 & $\mathrm{SD}$ & 20 & 50 \\
\hline 2 & SMP & 13 & 33 \\
\hline 3 & SMA & 3 & 8 \\
\hline 4 & D3/SARJANA & 4 & 10 \\
\hline & Jumlah & 40 & 100 \\
\hline
\end{tabular}
sebagian responden memiliki tingkat pendidikan SD berjumlah 20 responden (50\%) di Puskesmas Tembok Dukuh Surabaya.

4. Karakteristik Responden Berdasarkan Pekerjaan

Tabel 4 Karakteristik Responden Berdasarkan Pekerjaan

\begin{tabular}{cccc}
\hline No & Pekerjaan & $\mathbf{n}$ & $\%$ \\
\hline 1 & IRT/Tidak bekerja & 18 & 45 \\
2 & Pedagang & 17 & 43 \\
\hline
\end{tabular}

Tabel 4 (lanjutan) Karakteristik Responden Berdasarkan Pekerjaan

\begin{tabular}{llcc}
\hline No & Pekerjaan & n & \% \\
\hline 3 & Swasta & 2 & 5 \\
4 & PNS & 3 & 8 \\
\hline & Jumlah & 40 & 100 \\
\hline
\end{tabular}

Tabel 4 menunjukkan bahwa hampir sebagian besar responden tidak bekerja hanya sebagai IRT berjumlah 18 responden $(45 \%)$.

5. Karakteristik Responden Berdasarkan Penghasilan/Bulan

Tabel 5 Karakteristik Responden Berdasarkan Penghasilan per Bulan

\begin{tabular}{cccc}
\hline No & Penghasilan & n & $\%$ \\
\hline 1 & $<$ Rp. $500.000,00$ & 11 & 28 \\
2 & Rp. $500.000-1.000 .000$ & 6 & 15 \\
3 & Rp. $1.500 .000-2.000 .000$ & 16 & 40 \\
4 & Rp. $2.500 .000-3.000 .000$ & 2 & 5 \\
5 & $>$ Rp. 3.000 .000 & 5 & 13 \\
\hline & Jumlah & $\mathbf{4 0}$ & $\mathbf{1 0 0}$ \\
\hline
\end{tabular}

Tabel 5 menunjukkan bahwa sebagian besar responden memiliki penghasilan/bulan Rp.1.500.000 2.000.000 berjumlah 16 responden (40\%).

6. Karakteristik Responden Berdasarkan Berat Badan

Tabel 6 Karakteristik Responden Berdasarkan Berat Badan

\begin{tabular}{cccc}
\hline No & Berat Badan & $\mathrm{n}$ & $\%$ \\
\hline 1 & Kurus & 8 & 20 \\
2 & Normal & 10 & 25 \\
3 & Gemuk & 8 & 20 \\
4 & Obesitas & 14 & 35 \\
5 & Obesitas 1 & - & - \\
6 & Obesitas 2 & - & - \\
7 & Obesitas 3 & - & - \\
\hline \multicolumn{5}{c}{ Jumlah } & $\mathbf{4 0}$ & 100 \\
\hline Tabel & $6 \quad$ menunjukkan & bahwa
\end{tabular}
sebagian besar responden memiliki BB dengan kategori Obesitas dengan jumlah 14 responden $(35 \%)$.

Data Khusus

Tabel 7 Distribusi Frekuensi Responden

Berdasarkan Pola Makan Pada Penderita Diabetes Mellitus

\begin{tabular}{|c|c|c|c|}
\hline No & Pola Makan & $\mathrm{n}$ & $\%$ \\
\hline 1 & Baik & 11 & 28 \\
\hline 2 & Cukup & 15 & 38 \\
\hline \multirow[t]{2}{*}{3} & Kurang & 14 & 35 \\
\hline & Jumlah & 40 & 100 \\
\hline
\end{tabular}
distribusi frekuensi responden berdasarkan variabel pola makan di Puskesmas Tembok Dukuh sebagian dari responden pengaturan pola makannya 
cukup baik dengan jumlah 15 responden $(38 \%)$.

Tabel 8 Distribusi Frekuensi Responden

Berdasarkan Kadar Gula Darah Pada Penderita Diabetes Mellitus

\begin{tabular}{|c|c|c|c|}
\hline No & Kadar Gula & $\mathrm{n}$ & $\%$ \\
\hline 1 & Hipoglikemia & 9 & 23 \\
\hline 2 & Normal & 13 & 33 \\
\hline 3 & Hiperglikemia & 18 & 45 \\
\hline & Jumlah & 40 & 100 \\
\hline
\end{tabular}

Puskesmas Tembok Dukuh sebagian besar responden mengalami hiperglikemia dengan jumlah 18 responden (45\%).

Tabel 9 menunjukkan tingkat signifikasi $\mathrm{p}=0,000$ dengan $<0,05$ sehingga $\mathrm{H} 0$ ditolak. Hal ini membuktikan bahwa terdapat hubungan yang kuat antara pola makan dengan kadar gula darah pada penderita DM dengan Correlation Coefficient r $=0,634$.

Tabel 9 Distribusi Frekuensi Hubungan Pola Makan Dengan Kadar Gula Darah Pada Penderita Diabetes Mellitus

\begin{tabular}{ccccc}
\hline $\begin{array}{c}\text { Pola } \\
\text { Makan }\end{array}$ & Hipoglikemia & Kadar Gula Darah & TOTAL \\
& $1(3 \%)$ & $4(20 \%)$ & Hiperglikemia & 6 \\
Baik & $7(18 \%)$ & $6(15 \%)$ & $9(23 \%)$ & 22 \\
Cukup & $1(3 \%)$ & $5(13 \%)$ & $6(15 \%)$ & 12 \\
Kurang & & Hasil Uji Spearman $\mathrm{p}=0,00$ & \\
& & Correlation Coefficient $\mathrm{r}=0,634$ & \\
\hline
\end{tabular}

\section{PEMBAHASAN}

Hasil penelitian yang dilakukan di Puskesmas Tembok Dukuh Kecamatan Bubutan Kelurahan Tembok Dukuh Surabaya pada bulan Oktober-November 2017 tentang pola makan menunjukkan bahwa sebagian besar responden mempunyai pola makan yang cukup baik $(38 \%)$, dan masih terdapat responden dengan pola makan kurang baik (35\%), serta pengaturan pola makan yang baik $(28 \%)$.

Pola makan adalah suatu cara tertentu dalam mengatur jumlah dan jenis asupan makanan dengan maksud untuk mempertahankan kesehatan, status gizi, serta mencegah dan/atau membantu proses penyembuhan (Depkes, 2009). Pola makan yang baik harus dipahami oleh para penderita DM dalam pengaturan pola makan sehari-hari. Pola ini meliputi pengaturan jadwal bagi penderita DM yang biasanya adalah 6 kali makan per hari yang dibagi menjadi 3 kali makan besar dan 3 kali makan selingan. Adapun jadwal waktunya adalah makan pagi pukul 06.00-07.00, selingan pagi pukul 09.00-10.00, makan siang pukul 12.0013.00, selingan siang pukul 15.00-16.00, makan malam pukul 18.00-19.00, dan selingan malam pukul 21.00-22.00. Jumlah makan (kalori) yang dianjurkan bagi penderita DM adalah makan lebih sering dengan porsi kecil sedangkan yang tidak dianjurkan adalah makan dalam porsi yang besar, seperti makan pagi $(20 \%)$, selingan pagi $(10 \%)$, makan siang $(25 \%)$, selingan siang (10\%), makan malam (25\%), selingan malam (10\%). Jenis makanan perlu diperhatikan karena menentukan kecepatan naiknya kadar gula darah. Penyusunan makanan bagi penderita DM mencakup karbohidrat, lemak, protein, buah-buahan, dan sayuran (Tjokroprawiro, 2012; Dewi, 2013).

Hasil penelitian menunjukkan sebagian besar responden mempunyai pola makan yang cukup baik. Berdasarkan umur, hampir sebagian reponden berumur 46-55 (38\%), karena semakin tinggi umur semakin tinggi juga keperluan asupan gizinya. Berdasarkan jenis kelamin, sebagian besar responden berjenis kelamin perempuan (60\%) dikarenakan perempuan lebih sering makan makanan manis seperti coklat, gula dan jajanan siap saji dibandingka laki-laki.

Dilihat dari segi pendidikan sebagian besar responden memiliki tingkat pendidikan SD (50\%) sehingga pengetahuan yang kurang tentang pengaturan pola makan dapat memicu 
peningkatan kadar gula darah. Dilihat dari penghasilan per bulan, sebagian responden memiliki penghasilan sebesar Rp. 1.500.000-2.000.000,-.

Diabetes mellitus (DM) dikenal oleh masyarakat sebagai penyakit kencing manis atau penyakit menahun yang ditandai dengan adanya peningkatan kadar gula darah sebagai akibat dari adanya gangguan sistem metabolisme di dalam tubuh. Hal ini dapat disebabkan oleh gagalnya organ pankreas untuk memproduksi hormon insulin sesuai kebutuhan (Suiraoka, 2012). Penderita DM tetap diperbolehkan makan seperti orang normal tetapi harus mampu mengendalikannya baik dalam hal jadwal makan, jumlah, dan jenis makanan yang dikonsumsi (Sudarmingsih, 2006).

Hasil penelitian menunjukkan bahwa sebagian besar responden mengalami hiperglikemia (45\%). Berdasarkan berat badan hampir sebagian responden memiliki kategori obesitas. Hal ini dikarenakan penderita DM cenderung mengonsumsi makanan yang banyak mengandung gula dan berindeks glikemik tinggi sehingga akan memicu seseorang terkena diabetes. Selanjutnya, hal ini juga bisa memicu adanya resistensi insulin.

Berdasarkan uji statistik diketahui pola makan baik dengan karakteristik kadar gula darah hipoglikemia yaitu 1 orang $(3 \%)$, pola makan yang baik dengan karakteristik kadar gula darah normal yaitu 4 orang $(20 \%)$, pola makan baik dengan karakteristik kadar gula darah hiperglikemia yaitu 1 (3\%), pola makan cukup baik dengan karakteristik kadar gula darah hipoglikemia yaitu 7 orang $(18 \%)$, pola makan cukup baik dengan karakteristik kadar gula darah normal yaitu 6 orang $(15 \%)$, pola makan cukup baik dengan karakteristik kadar gula darah hiperglikemia yaitu 9 orang (23\%), pola makan kurang baik dengan karakteristik hipoglikemia yaitu 1 orang (3\%), pola makan kurang baik dengan karakteristik kadar gula darah normal yaitu 5 orang $(13 \%)$, pola makan kurang baik dengan karakteristik kadar gula darah hiperglikemia yaitu 6 orang $(15 \%)$.

Hasil uji statistik menyimpulkan adanya hubungan antara pola makan dengan kadar gula darah yang ada pada penderita DM. Pola makan memegang peranan penting bagi penderita DM seseorang yang tidak bisa mengatur pola makan dengan pengaturan 3J (jadwal, jenis dan jumlah) maka hal ini akan menyebabkan penderita mengalami peningkatan kadar gula darah (Suiraoka, 2012). Pola makan penderita DM harus benar-benar diperhatikan.

Penderita DM biasanya cenderung memiliki kandungan gula darah yang tidak terkontrol (Susanto, 2013). Kadar gula darah akan meningkat dratis setelah mengkonsumsi makanan yang banyak mengandung karbohidrat dan/atau gula (Nurrahmani, 2012). Oleh karena itu, penderita DM perlu menjaga pengaturan pola makan dalam rangka pengendalian kadar gula darah sehingga kadar gula darahnya tetap terkontrol.

PENUTUP

Penelitian ini menunjukkan adanya hubungan antara pola makan dengan kadar gula darah pada penderita Diabetes Mellitus di Puskesmas Tembok Dukuh Surabaya. Responden dianjurkan agar tetap mempertahankan kestabilan kadar gula darahnya dengan pengaturan pola makan yang tepat sesuai dengan anjuran 3J (Jadwal, Jumlah dan Jenis).

\section{DAFTAR PUSTAKA}

Dewi (2013). Menu Sehat 30 Hari untuk Mencegah dan Mengatasi Diabetes. Jakarta: Media Pustaka.

Krisnatuti \& Yehrina. (2008). Diet Sehat untuk Penderita Diabetes Mellitus. Jakarta: Penebar Swadaya.

Notoatmodjo, S. (2010). Konsep dan Penerapan Metodologi Penelitian Ilmu Keperawatan. Jakarta: Salemba Medika.

Nurrahmani. (2012). Stop! Diabetes. Yogyakarta : Araska.

Nursalam. (2013). Metodologi Penelitian Ilmu Keperawatan Pendekatan Praktis. Jakarta: Salemba Medika.

Soegondo. (2015). Penatalaksanaan Diabetes Mellitus Terpadu. Jakarta: Balai Penerbit FKUI.

Suiraoka. (2012). Penyakit Degeneratif. Yogyakarta: Nuhamedika. 
Hubungan Pola Makan Dengan Kadar Gula Darah Pada ...

Sudarmingsih. (2006). Pola makan dengan kejadian sindroma metabolik. Semarang: Prosiding Temu Ilmiah Asdie.

Susanto, T. (2013). Diabetes, Deteksi, Pencegahan, Pengobatan. Jakarta: Buku Pintar ISBN.

Susilo. (2012). Diet Diabetes!. Jakarta: Salemba Medika.
Tandra. (2009). Segala Sesuatu Yang Harus Anda Ketahui Tentang Diabetes. Jakarta: Kompas Gramedia.

Tjokroprawiro. A. (2012). Garis Besar Pola Makan dan Pola Hidup Sebagai Pendukung Terapi DiabetesMellitus. Surabaya: Fakultas Kedokteran Unair. 